\title{
EFFECTIVE TAX RATE IN V4 COUNTRIES AND SERBIA - SECTORAL APPROACH
}

\author{
Michał Biernacki*, \\ Piotr Luty \\ Wroclaw University of \\ Economics and Business, \\ Wroclaw, Poland
}

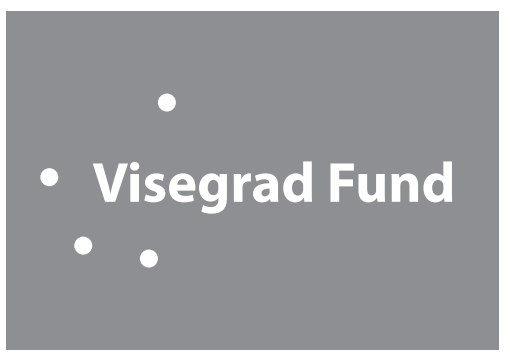

Correspondence:

Michał Biernacki

e-mail:

michal.biernacki@ue.wroc.pl

\begin{abstract}
:
The study aims to investigate whether there were positive relationships between the size of the companies (LNA) and the effective tax rate in individual sectors of economic activity in the Visegrad countries and Serbia. The Political Cost Theory could explain the positive relationship. The analysis was carried out using regression analysis for individual sectors (BvD sector classification) and countries. The results indicate that there is a need for further research and extension to new reporting periods and variables.
\end{abstract}

\section{Keywords:}

Visegrad, tax avoidance, effective tax rate.

\section{INTRODUCTION}

Running a business is associated with the obligation to pay taxes. From the financial perspective of companies, paying the tax is associated with a reduction in cash that the company could spend on other purposes. For this reason, in developing countries, where awareness of corporate social responsibility is still weak, there may be a desire to avoid tax, understood as reducing the tax burden. Tax avoidance can be explained based on agency theory ( Badertscher et al., 2013). According to this theory, companies have two groups of stakeholders who often have opposite goals. The first group consists of owners, often called principals in the agency's theory. The second group consists of people managing the company - the so-called agents. According to the agency's theory, owners may prefer tax avoidance activities, as they will be able to use the additional funds obtained in this way for their purposes ( Kovermann, Velte, 2019).

On the other hand, investors (owners) may be reluctant to adopt tax avoidance practices that may be associated with higher tax risks or potential penal and fiscal sanctions. Based on the literature review, the following factors determining tax behaviour are listed: the amount of the tax rate, penalties and probability of detecting tax irregularities, risk aversion of tax decision-makers (Hanlon, 2010). Additionally, it can be noticed that in developed countries, there may also be a factor related to the reputation and perception of the company's tax behaviour by third parties. Austin and Wilson (2017) indicate the influence of consumers and their perception of the company on the phenomenon of tax avoidance. There is much research into the impact of ownership structure on tax avoidance.

Chen et al. (2019), Huseynov et al. (2017), Khan et al. (2016) noted that increasing the share of institutional owners leads to increased tax avoidance. 
The opposite conclusions were revealed in the studies (Shleifer, Vishny, 1986; Khurana, Moser 2012). Discrepancies in research results indicate that tax avoidance is a complex process and that in different cultural, political and economic conditions, various factors may be decisive in reducing the tax burden.

Regardless of the ownership structure, the reduction of the tax burden may also result from the preferential treatment of selected segments of economic activity by public authorities. There may be detailed regulations in the tax system regarding the eligibility of costs, which affect the reduction or increase of the tax base. Tax benefits may apply to innovative companies in order to encourage new investors to set up a business in the territory of the selected country. Special treatment may also apply to companies which, by contributing to the labour market, support the inhabitants of a given country. Finally, tax advantages may apply to strategically important companies, which are often also controlled directly or indirectly by state authorities. Detailed regulations of tax law may, therefore, affect the development or inhibition of a given sector of economic activity. Therefore, a research question arises as to how the effective tax rate is shaped in individual sectors of economic activity, which is also a measure of tax avoidance.

An essential determinant of tax avoidance is the size of the companies. There are two theories related to the influence of the size of companies on the tax burden: Political Power Theory ( PPT ) and Political Cost Theory ( PCT ). According to the PPT, larger companies bear lower tax burdens (there is a negative relationship between the company's size and the effective tax rate). It may result from the greater possibility of influencing tax decisions (the theory is described in more detail in Belz et al. (2019) ). According to PCT, there is a positive relationship between the size of the companies and the effective tax rate. This situation may occur when higher tax burdens are shifted to companies that are more profitable or larger in terms of assets (the theory is described in more detail in Belz et al. (2019)). It may result from the belief that a large company, thanks to its organizational and financial resources, will be able to bear the higher tax burden.

The article aims to analyze the impact of company size on the effective tax rate in the Visegrad countries (Poland, the Czech Republic, Slovakia, Hungary) and Serbia. To check if there are specific business sectors where PPTs or PCTs apply, and the analysis will be performed for 2018. It is a pilot study that will be extended to the next reporting years in the future. A research hypothesis can be made:

$\mathrm{H1}$ : There is a positive correlation between the size of companies and the effective tax rate in selected sectors.

\section{RESEARCH SAMPLE AND METHODOLOGY}

The research sample covers five countries: Poland, the Czech Republic, Slovakia, Hungary and Serbia. The choice of the Visegrad countries is because they are developing countries, with a similar political history, joining the European Union at the same time. The extension of the study to include companies from Serbia is based on the assumptions of the IVF grant number 22010083. The study was limited to 2018 due to the preliminary nature of the study.

The financial data comes from the BvD Orbis database, in which the following search criteria were assumed:

1. Status - active companies

2. World region / Country / Region in country - Czech Republic, Hungary, Poland, Serbia, Slovakia

3. Accounting practice - IFRS, Local GAAP

4. Total assets ( $\mathrm{m} \mathrm{USD}$ ) $-\mathrm{min}=0$ in years 2018,2017 , 2016, 2015, 2014,

5. Taxation (m USD) $-\min =0$ in years 2018,2017 , 2016, 2015, 2014,

6. $\mathrm{P} / \mathrm{L}$ before tax ( $\mathrm{m} \mathrm{USD})-\min =0$ in years 2018 , 2017, 2016, 2015, 2014,

7. Size classification - Large, Medium, Very large

The final research sample required the introduction of additional selection steps:

1. eliminating companies that did not have an assigned classification of economic activities,

2. elimination of companies whose financial data was incomplete,

3. elimination of the banking sector,

4. limiting the effective tax rate to the range (0-1).

The introduced exclusions were used to limit the erroneous inference due to missing or incomplete data. Removal from further analysis of the banking sector resulted from the fact that this sector has specific legal regulations. Table 1 shows the final number of companies included in the study by country.

Table 1. Final research sample

\begin{tabular}{|c|c|}
\hline Country & number \\
\hline $\mathrm{CZ}$ & 12720 \\
\hline PL & 14608 \\
\hline $\mathrm{RS}$ & 5084 \\
\hline SK & 8382 \\
\hline $\mathrm{HU}$ & 20425 \\
\hline Total & 61219 \\
\hline
\end{tabular}


Table 2 shows the companies broken down into sectors - BvD Sector.

Table 2. Research sample - sector classification

\begin{tabular}{|c|c|c|c|c|c|c|}
\hline Sector & $\mathrm{CZ}$ & $\mathrm{PL}$ & RS & SK & $\mathrm{HU}$ & Total \\
\hline $\begin{array}{l}\text { Agriculture, } \\
\text { Horticulture \& } \\
\text { Livestock }\end{array}$ & 777 & 114 & 157 & 290 & 805 & 2143 \\
\hline $\begin{array}{l}\text { Biotechnology } \\
\text { and Life } \\
\text { Sciences }\end{array}$ & 49 & 78 & 29 & 16 & 95 & 267 \\
\hline $\begin{array}{l}\text { Business } \\
\text { Services }\end{array}$ & 1407 & 1317 & 472 & 1398 & 2463 & 7057 \\
\hline $\begin{array}{l}\text { Chemicals, } \\
\text { Petroleum, } \\
\text { Rubber \& Plastic }\end{array}$ & 415 & 642 & 178 & 177 & 419 & 1831 \\
\hline Communications & 85 & 74 & 26 & 34 & 109 & 328 \\
\hline $\begin{array}{l}\text { Computer } \\
\text { Hardware }\end{array}$ & 9 & 7 & 34 & 4 & 8 & 62 \\
\hline $\begin{array}{l}\text { Computer } \\
\text { Software }\end{array}$ & 354 & 361 & 89 & 159 & 417 & 1380 \\
\hline Construction & 1201 & 1264 & 410 & 697 & 2292 & 5864 \\
\hline $\begin{array}{l}\text { Food \& Tobacco } \\
\text { Manufacturing }\end{array}$ & 278 & 530 & 326 & 147 & 602 & 1883 \\
\hline $\begin{array}{l}\text { Industrial, Electric } \\
\text { \& Electronic } \\
\text { Machinery }\end{array}$ & 811 & 672 & 188 & 338 & 761 & 2770 \\
\hline $\begin{array}{l}\text { Information } \\
\text { Services }\end{array}$ & 2 & 4 & 2 & 2 & 3 & 13 \\
\hline $\begin{array}{l}\text { Leather, Stone, } \\
\text { Clay \& Glass } \\
\text { products }\end{array}$ & 155 & 220 & 35 & 55 & 159 & 624 \\
\hline $\begin{array}{l}\text { Media \& } \\
\text { Broadcasting }\end{array}$ & thirty & 81 & 18 & 11 & 80 & 220 \\
\hline $\begin{array}{l}\text { Metals \& Metal } \\
\text { Products }\end{array}$ & 787 & 767 & 206 & 449 & 821 & 3030 \\
\hline
\end{tabular}

\begin{tabular}{|c|c|c|c|c|c|c|}
\hline $\begin{array}{l}\text { Mining \& } \\
\text { Extraction }\end{array}$ & 43 & 82 & 18 & 22 & 45 & 210 \\
\hline $\begin{array}{l}\text { Miscellaneous } \\
\text { Manufacturing }\end{array}$ & 56 & 40 & 18 & 15 & 43 & 172 \\
\hline $\begin{array}{l}\text { Printing \& } \\
\text { Publishing }\end{array}$ & 79 & 140 & 80 & 50 & 159 & 508 \\
\hline Property Services & 738 & 862 & 39 & 406 & 943 & 2988 \\
\hline $\begin{array}{l}\text { Public } \\
\text { Administration, } \\
\text { Education, Health } \\
\text { Social Services }\end{array}$ & 187 & 465 & 15 & 136 & 245 & 1048 \\
\hline Retail & 461 & 896 & 336 & 883 & 2736 & 5312 \\
\hline $\begin{array}{l}\text { Textiles \& Clothing } \\
\text { Manufacturing }\end{array}$ & 101 & 179 & 153 & 89 & 216 & 738 \\
\hline $\begin{array}{l}\text { Transport } \\
\text { Manufacturing }\end{array}$ & 169 & 152 & 31 & 65 & 96 & 513 \\
\hline $\begin{array}{l}\text { Transport, Freight } \\
\text { \& Storage }\end{array}$ & 610 & 713 & 328 & 497 & 1157 & 3305 \\
\hline $\begin{array}{l}\text { Travel, Personal } \\
\text { \& Leisure }\end{array}$ & 309 & 313 & 142 & 286 & 1091 & 2141 \\
\hline Utilities & 416 & 487 & 57 & 125 & 88 & 1173 \\
\hline $\begin{array}{l}\text { Waste Management } \\
\text { \& Treatment }\end{array}$ & 158 & 200 & 57 & 63 & 130 & 608 \\
\hline Wholesale & 2799 & 3515 & 1474 & 1809 & 4111 & 13708 \\
\hline $\begin{array}{l}\text { Wood, Furniture } \\
\text { \& Paper } \\
\text { Manufacturing }\end{array}$ & 234 & 433 & 166 & 159 & 331 & 1323 \\
\hline Total & 12720 & 14608 & 5084 & 8382 & 20425 & 61219 \\
\hline
\end{tabular}

In the analyzed countries, different corporate income tax rates had an impact on the effective tax rate (ETR) value. Table 3 shows the descriptive statistics for the effective tax rate (ETR) for Poland, the Czech Republic, Slovakia, Hungary and Serbia in 2018, 2017 and 2016.

Table 3. Effective tax rate in V4 countries and Serbia

\begin{tabular}{lccccccr}
\hline \multicolumn{1}{r}{ Variable } & $\begin{array}{c}\text { Country ISO } \\
\text { code }\end{array}$ & Valid N & Mean & Median & Minimum & Maximum & Std.Dev . \\
\hline ETR 2018 & CZ & 12720 & 0.1993 & 0.1926 & 0.0000 & 1.0000 & 0.1035 \\
\hline ETR 2017 & CZ & 12720 & 0.1946 & 0.1923 & 0.0000 & 1.0000 & 0.1004 \\
\hline ETR 2016 & CZ & 12720 & 0.1936 & 0.1925 & 0.0000 & 1.0000 & 0.1056 \\
\hline ETR 2018 & PL & 14608 & 0.2234 & 0.1987 & 0.0000 & 1.0000 & 0.1159 \\
\hline ETR 2017 & PL & 14608 & 0.2219 & 0.1989 & 0.0001 & 1.0000 & 0.1121 \\
\hline ETR 2016 & PL & 14608 & 0.2216 & 0.1991 & 0.0001 & 1.0000 & 0.1086 \\
\hline ETR 2018 & SK & 8382 & 0.2476 & 0.2200 & 0.0000 & 1.0000 & 0.1272 \\
\hline ETR 2017 & SK & 8382 & 0.2456 & 0.2196 & 0.0000 & 1.0000 & 0.1248 \\
\hline ETR 2016 & SK & 8382 & 0.2548 & 0.2289 & 0.0000 & 1.0000 & 0.1324 \\
\hline ETR 2018 & RS & 5084 & 0.1425 & 0.1461 & 0.0000 & 0.9722 & 0.1134 \\
\hline ETR 2017 & RS & 5084 & 0.1337 & 0.1419 & 0.0000 & 0.9908 & 0.1034 \\
\hline ETR 2016 & RS & 5084 & 0.1264 & 0.1341 & 0.0000 & 1.0000 & 0.1028 \\
\hline ETR 2018 & HU & 20425 & 0.1151 & 0.0893 & 0.0000 & 1.0000 & 0.1361 \\
\hline ETR 2017 & HU & 20425 & 0.1098 & 0.0892 & 0.0000 & 0.9985 & 0.1256 \\
\hline ETR 2016 & HU & 20425 & 0.1179 & 0.0987 & 0.0000 & 0.9984 & 0.1276 \\
\hline
\end{tabular}

Source: own study 
Based on Table 3, it can be concluded that the lowest tax burden (median of the ETR variable) was in Hungary and the highest in Slovakia. Due to different national income tax rates, a further sectoral analysis will be country-by-country.

In order to answer the research question posed in the article and verify the research hypothesis, the following variables will be used:

- ETR - effective tax rate is based on data from financial statements - profit and loss account. This method of calculating the ETR variable is used when making decisions by companies (Graham et al., 2013, Kraft, 2014), an independent variable in the study.

$$
E T R=\frac{\text { income tax }(\text { actual }+ \text { deferred })}{\text { gross profit or loss }}
$$

- LNA - Company size can be measured in many ways. A standard measure of company size applicable to companies listed on regulated capital markets and private companies is a measure based on the size of the balance sheet total (Lazar, 2014, Jiménez- Angueira, 2018).

\section{$L N A=\ln ($ total assets $)$}

The verification of the hypothesis will be carried out with the use of linear regression analysis.

\section{RESEARCH RESULTS}

The article hypothesizes that there is a positive correlation between the size of companies and the effective tax rate in selected sectors of economic activity. The results of the regression analysis for individual sectors of economic activity and the countries selected in the study: Poland, the Czech Republic, Slovakia, Serbia and Hungary are presented in Table 4 . Table 4 uses the following designations for the test results:

- "Positive " means the positive sign to the regression coefficient for the LNA variable

- "Negative " means the negative sign of the regression coefficient for the LNA variable

- “ no sign. " means no statistically significant coefficient at the level of $5 \%$.

Table 4. Regression results in $\mathrm{BvD}$ sectors

\begin{tabular}{|c|c|c|c|c|c|c|}
\hline Variable & BvD Sector & PL & $\mathrm{CZ}$ & SK & RS & HU \\
\hline LNA 2018 & Agriculture, Horticulture \& Livestock & no sign. & no sign. & no sign. & no sign. & negative \\
\hline LNA 2018 & Biotechnology and Life Sciences & no sign. & no sign. & no sign. & no sign. & negative \\
\hline LNA 2018 & Business Services & negative & no sign. & negative & no sign. & negative \\
\hline LNA 2018 & Chemicals, Petroleum, Rubber \& Plastic & no sign. & no sign. & no sign. & no sign. & negative \\
\hline LNA 2018 & Communications & no sign. & no sign. & no sign. & no sign. & no sign. \\
\hline LNA 2018 & Computer Hardware & no sign. & no sign. & no sign. & no sign. & no sign. \\
\hline LNA 2018 & Computer Software & no sign. & no sign. & no sign. & no sign. & negative \\
\hline LNA 2018 & Construction & no sign. & no sign. & no sign. & no sign. & negative \\
\hline LNA 2018 & Food \& Tobacco Manufacturing & no sign. & no sign. & no sign. & no sign. & negative \\
\hline LNA 2018 & Industrial, Electric \& Electronic Machinery & no sign. & no sign. & no sign. & no sign. & negative \\
\hline LNA 2018 & Information Services & no sign. & no sign. & no sign. & no sign. & no sign. \\
\hline LNA 2018 & Leather, Stone, Clay \& Glass products & no sign. & no sign. & no sign. & no sign. & negative \\
\hline LNA 2018 & Media \& Broadcasting & no sign. & no sign. & negative & no sign. & no sign. \\
\hline LNA 2018 & Metals \& Metal Products & negative & no sign. & no sign. & no sign. & negative \\
\hline LNA 2018 & Mining \& Extraction & no sign. & no sign. & no sign. & no sign. & no sign. \\
\hline LNA 2018 & Miscellaneous Manufacturing & no sign. & no sign. & no sign. & no sign. & no sign. \\
\hline LNA 2018 & Printing \& Publishing & no sign. & no sign. & no sign. & no sign. & negative \\
\hline LNA 2018 & Property Services & no sign. & no sign. & no sign. & no sign. & negative \\
\hline LNA 2018 & $\begin{array}{l}\text { Public Administration, Education, Health } \\
\text { Social Services }\end{array}$ & negative & no sign. & no sign. & no sign. & negative \\
\hline LNA 2018 & Retail & no sign. & no sign. & no sign. & no sign. & negative \\
\hline LNA 2018 & Textiles \& Clothing Manufacturing & no sign. & no sign. & no sign. & no sign. & negative \\
\hline LNA 2018 & Transport Manufacturing & no sign. & no sign. & no sign. & no sign. & negative \\
\hline LNA 2018 & Transport, Freight \& Storage & negative & no sign. & no sign. & positive & negative \\
\hline LNA 2018 & Travel, Personal \& Leisure & no sign. & no sign. & no sign. & no sign. & negative \\
\hline LNA 2018 & Utilities & no sign. & no sign. & no sign. & no sign. & positive \\
\hline LNA 2018 & Waste Management \& Treatment & no sign. & negative & no sign. & no sign. & no sign. \\
\hline LNA 2018 & Wholesale & no sign. & positive & no sign. & no sign. & negative \\
\hline LNA 2018 & Wood, Furniture \& Paper Manufacturing & no sign. & no sign. & no sign. & no sign. & negative \\
\hline
\end{tabular}


Table 4 shows that only in three sectors, there was a positive correlation between the size of the companies and the effective tax rate. A positive correlation appeared for the Wholesale sector in the Czech Republic; Transport, Freight \& Storage in Serbia and Utilities in Hungary. It means that the PCT theory has a limited application for the Visegrad countries and Serbia. The negative correlation between the size of companies and the effective tax rate was much more frequent, according to the theory of PPT. Especially in Hungary, a situation in which large companies have lower tax burdens was noticeable. In 20 sectors in Hungary, there was a negative correlation between the size of the companies and ETR. For most sectors in Poland, the Czech Republic, Slovakia and Serbia, the regression analysis did not reveal any significant statistical coefficients for the LNA variable - company size. It means that the LNA variable did not alter the ETR. It may result from the complexity of the phenomenon of tax avoidance or the development of dependence other than linear.

\section{CONCLUSION}

The article aimed to analyze the impact of the size of companies (measured by the natural logarithm of total assets) on the effective tax rate in Poland, the Czech Republic, Slovakia, Hungary and Serbia. According to Political Cost Theory, there are specific sectors of economic activity in which there is a positive correlation. The results of the linear regression analysis show that only in 3 cases, a positive correlation was observed between the size of the companies and the effective tax rate. The hypothesis put forward in the study was only partially positively verified. The results of the study indicate that there may be other factors that, in combination with the size of companies, might be in line with the Political Cost Theory. The study of dependencies in developing countries: the Visegrad countries and Serbia, requires deepening. Based on Belz et al. (2019), there are publications in which the authors show no statistically significant relationship between the size of the companies and ETR.

The limitation of the study is the limitation of the study to 1 year - 2018. This limitation is due to the preliminary nature of the study. Additionally, future research will include the analysis of more variables.

\section{ACKNOWLEDGMENT}

This paper is part of the project No. 22010083 entitled "Experience sharing of Visegrad countries to tax avoid activity" financed by the International Visegrad Fund.

\section{LITERATURE}

Austin, CR, \& Wilson, RJ (2017). An examination of reputational costs and tax avoidance: Evidence from firms with valuable consumer brands. The Journal of the American Taxation Association, 39 (1), 67-93.

Badertscher, B. A., Katz, S. P., \& Rego, S. O. (2013). The separation of ownership and control and corporate tax avoidance. Journal of Accounting and Economics, 56(2-3), 228-250.

Belz, T., von Hagen, D., \& Steffens, C. (2019). Taxes and firm size: Political cost or political power?. Journal of Accounting Literature, 42, 1-28.

Chen, S., Huang, Y., Li, N., \& Shevlin, T. (2019). How does quasi-indexer ownership affect corporate tax planning? Journal of Accounting and Economics, 67(2-3), 278-296

Graham, J. R., Hanlon, M., Shevlin, T., \& Shroff, N. (2013). Incentives for tax planning and avoidance: Evidence from the field. The Accounting Review, 89(3), 991-1023.

Hanlon, M., \& Heitzman, S. (2010). A review of tax research. Journal of accounting and Economics, 50(2-3), 127-178.

Huseynov, F., Sardarli, S., \& Zhang, W. (2017). Does index addition affect corporate tax avoidance?. Journal of Corporate Finance, 43, 241-259.

Jiménez-Angueira, C. E. (2018). The effect of the interplay between corporate governance and external monitoring regimes on firms' tax avoidance. Advances in Accounting, 41, 7-24.

Khan, M., Srinivasan, S., \& Tan, L. (2016). Institutional ownership and corporate tax avoidance: New evidence. The Accounting Review, 92(2), 101-122.

Khurana, I. K., \& Moser, W. J. (2012). Institutional shareholders' investment horizons and tax avoidance. The Journal of the American Taxation Association, 35(1), 111-134.

Kovermann, J., \& Velte, P. (2019). The impact of corporate governance on corporate tax avoidance-A literature review. Journal of International Accounting, Auditing and Taxation, 36, 100270.

Kraft, A. (2014). What really affects German firms' effective tax rate?. International Journal of Financial Research, 5(3), 1-19.

Lazăr, S. (2014). Determinants of the variability of corporate effective tax rates: Evidence from Romanian listed companies. Emerging Markets Finance and Trade, 50(sup4), 113-131.

Shleifer, A., \& Vishny, R. W. (1986). Large shareholders and corporate control. Journal of political economy, 94(3, Part 1), 461-488. 